8. Telander B, Lerner R, Palmblad J, Ringertz O. Corynebacterium group JK in a hematological ward: infections, colonization and environmental contamination. Scand J Infect Dis 1988;20(1):55-61. Abstract.

9. Kuhn PJ. Doorknobs: a source of nosocomial infections? Diagn Med $1983 ; 6(8): 62-63$

10. Shafer Environmental Associates, Ltd. Staff. Published exposure limits listed by chemical name. In: Shafer D, ed. The Book Of Chemical Lists. Madison, CT: Business and Legal Reports: 1991;1:70-227.

11. Blair WR, Olson GJ, Trout TK Jewett KL, Brinckman FE. Accumulation and Fate of Tributyltin Species in Microbial Biofilms. US Department of Commerce, NIST 1988; NISTIR 88-3852

12. James AM. Molecular aspects of biological surfaces. Chem Soc Rev 1979;8:389-418.

13. Elliot HA, Huang CP. Absorption characteristics of heavy metals. Environ Int 1979;2:45-55.

14. James AM. The electrical properties and topochemistry of bacterial cells. Adv ColloidInterface Sci1982;15:171-221.

15. Doyle RJ. How cell walls of gram-positive bacteria interact with metal ions.
In: Beveridge TJ, Doyle RJ, eds. Metal Ions and Bacteria. New York, NY: Wiley \& Sons; $1989: 275-293$.

16. Ferris FG. Metallic ion interactions with the outer membrane of gram negative bacteria. In: Beveridge TJ. Doyle RJ, eds. Metal Ions and Bacteria. New York, NY: Wiley \& Sons; 1989295323.

17. Doyle RJ, Matthews TH, Streips UN. Chemical basis for selectivity of metal ions by the Bacillus subtilis cell wall. J Bacteriol 1980;143(1):471-480.

18. Tetaz TJ, Luke RKJ. Plasmid-controlled resistance to copper in Escherichia coli J Bacteriol 1983;154:1263-1268.

19. Brown NL, Camakaris J, Lee BTO, et al. Bacterial resistance to mercury and copper. J Cell Biochem 1991;46:106-114.

20. Cooksey DA, Azad HR, Cha JS, Lim CK. Copper resistance gene homologs in pathogenic and saprophytic bacterial species from tomatoes. ApplEnviron Microbiol 1990;56(2):431-435.

21. Brown NL, Rouch DA Lee BTO. Copper resistance determinants in bacteria. Plasmid1992:27:41-51.

\title{
CDC Issues Ebola Guidelines as Cases Continue to Occur
}

\section{by Gina Pugliese, RN, MS Medical News Editor}

Although the incidence of viral hemorrhagic fever (VHF) related to Ebola Virus in Kikwit (Zaire) has diminished, cases continue to occur, and each case has the potential to be a source for additional cases. As of June 25, 1995, 296 persons with Ebola VHF have been identified in Kikwit and the surrounding Bandundu region, with $79 \%$ of the cases being fatal.

Over $32 \%$ of the cases occurred in healthcare workers. Within households, the risk for developing VHF was higher for spouses of the primary household cases than for other household members. Risk factors among secondary cases included having direct contact with blood, vomitus, or stool of the ill person during his or her hospitalization, or simultaneously sharing the hospital bed of an Ebola patient. No cases developed in household members who had no physical contact with the primary household case patient during their clinical illness.

Transmission associated with healthcare providers and caregivers has been a prominent feature of the current and previous VHF outbreaks in Africa attributable to Lassa, Marburg, Ebola, and Crimean-Congo hemorrhagic fever viruses. In some outbreaks, transmission from patient to patient within hospitals has been associated with the reuse of unsterile needles and syringes. As in previous outbreaks, high rates of transmission have occurred from patients to healthcare workers and to family members who provided nursing care without appropriate barrier precautions. The risk of transmission appears to be highest during the later stages of illness, and infection has not been reported in persons whose contact with an infected patient occurred only during the incubation period (before the patient became febrile).

On June 20, 1995, the CDC issued updated guidelines for the management of patients with suspected viral hemorrhagic fever in healthcare settings in the United States. These guidelines include barrier precautions for all persons entering the room to prevent exposure to infected blood or body fluids and potentially contaminated environmental surfaces. Although airborne transmission involving humans has never been documented and is considered a possibility only in rare instances from persons with advanced disease, the guidelines recommend the use of a negative-pressure room and a highefficiency particulate air respirator for persons entering the room. Special precautions are outlined for handling clinical specimens, contaminated sharps, soiled linens, and postmortem procedures. Contaminated environmental surfaces or inanimate objects can be cleaned and disinfected using standard procedures and any US EPAregistered hospital disinfectant or a 1:100 dilution of household bleach. Although there is no evidence for transmission of hemorrhagic fever virus to humans or animals through contact with sewage, as an added precaution and because the reservoir is unknown, it is recommended that bulk body fluids be either autoclaved, processed in a chemical toilet, or treated with household bleach before disposing in a drain connected to a sanitary sewer.

Pending a comprehensive review of the 1988 guidelines, these guidelines provide interim recommendations. All suspected cases of infection with Ebola virus and other hemorrhagic fever viruses should be reported immediately to local and state health departments and to the CDC (telephone (404) 639-1511; from 4:30 PM to 8:00 PM telephone (404) 6392888). For general information regarding Ebola virus infection, call the CDC Ebola Hotline (telephone (800) 9000681).

FROM: CDC. Update: management of patients with suspected viral hemorrhagic fever-United States. MMWR June 30, 1995;44(25):475-479.

CDC. Update: outbreak of Ebola viral hemorrhagic fever-Zaire, 1995. MMWR June 30, 1995;44(25):468469,475 . 